\title{
PERALIHAN PEMEGANG HAK TANGGUNGAN ATAS AKUISISI PERSEROAN TERBATAS
}

\author{
David Prasetyo \\ Magister Kenotariatan Fakultas Hukum Universitas Airlangga \\ davidprasetyo@gmail.com
}

\begin{abstract}
The purpose of this paper is to examine the transfer of a mortgage right holder for the acquisition of a limited liability company as a rights holder. The method used is a normative research method. The acquisition becomes a more prospective choice compared to other rescue patterns. The company took over PT. Bank Pundi Indonesia became a business license on behalf of PT. Banten Regional Development Bank, this led to a change in name that caused legal uncertainty regarding the security of the mortgage. Whereas before the ownership of mortgage rights guarantees or mortgage rights holders were the first company.
\end{abstract}

Keywords: Acquisition; Limited Liability Company; Mortgage Right.

\begin{abstract}
Abstrak
Tujuan Penulisan ini adalah untuk mengkaji peralihan pemegang hak tanggungan atas akuisisi sebuah perseroan terbatas sebagai pemegang hak. Metode yang digunakan adalah metode penelitian normatif. Akuisisi menjadi pilihan yang lebih memiliki prospek dibanding dengan pola penyelamatan lainnya. Adanya pengambilalihan perusahaan PT. Bank Pundi Indonesia menjadi izin usaha atas nama PT. Bank Pembangunan Daerah Banten, hal ini menyebabkan perubahan nama yang menimbulkan ketidakpastian hukum terhadap jaminan hak tanggungan tersebut. Padahal sebelumnya kepemilikan jaminan hak tanggungan atau pemegang jaminan hak tanggungan adalah perusahaan yang pertama.
\end{abstract}

Kata Kunci: Akuisisi; Perseroan Terbatas; Hak-Tanggungan;

\section{PENDAHULUAN}

Bentuk jaminan yang paling banyak digunakan sebagai agunan dalam perjanjian kredit bank adalah hak atas tanah baik dengan status Hak Milik, Hak Guna Usaha, Hak Guna Bangunan maupun Hak Pakai karena pada umumnya memiliki nilai atau harga yang tinggi dan terus meningkat sehingga dalam hal ini sudah selayaknya apabila debitur sebagai penerima kredit dan kreditur sebagai pemberi fasilitas kredit serta pihak lain terkait memperoleh perlindungan melalui suatu lembaga hak jaminan yang kuat dan dapat memberikan kepastian hukum.

Berdasarkan ketentuan dalam Pasal 51 Undang-Undang Nomor 5 Tahun 1960 tentang Peraturan Dasar Pokok-Pokok Agraria disebutkan bahwa sudah disediakan lembaga hak jaminan yang kuat dan dapat dibebankan pada hak atas tanah, yaitu Hak Tanggungan sebagai pengganti lembaga hypotheek dan creditverband. Selama 30 tahun lebih sejak mulai berlakunya Undang-Undang Pokok Agraria tersebut, lembaga hak tanggungan ini belum dapat berfungsi sebagaimana mestinya karena belum ada undang-undang yang mengaturnya secara lengkap, serta ketentuan dalam peraturan

David Prasetyo, Peralihan Pemegang Hak Tanggungan Atas Akuisisi Perseroan Terbatas. 
tersebut sudah tidak sesuai dengan Asas Hukum Tanah Nasional dan kurang memenuhi kebutuhan ekonomi di bidang perkreditan. ${ }^{1}$

Terbitnya Undang-Undang Nomor 4 Tahun 1996 tentang Hak Tanggungan Atas Tanah Beserta Benda-Benda Yang Berkaitan Dengan Tanah (UUHT) belum dapat mengatasi hambatan-hambatan yang jelas dalam pelaksanaannya terkait Hak Tanggungan. Diterapkannya UUHT mengharuskan perubahan dan persamaan persepsi serta sikap oleh semua pihak yang tersangkut dengan keberadaan lernbaga hak tanggungan (UUHT) yakni kreditur (termasuk bank), debitur, notaris, PPAT, kantor pertanahan, dan pengadilan. Kesamaan persepsi dan sikap akan berpengaruh terhadap pelayanan lembaga serta aparat secara profesional, akurat, dan tepat waktu sehirgga UUHT dapat diterima sebagai produk hukum yang bermanfaat dan menjamin kepastian hukum.

UUHT dimaksud untuk memberikan landasan bagi suatu lembaga hak jaminan yang kuat dan kepastian hukum bagi semua pihak yang berkepentingan secara seimbang. Dalam proses pemberian, pendaftaran, dan hapusnya hak tanggungan oleh pemegang jaminan hak tanggungan dapat melalui proses cessie, subrogasi, pewarisan, atau sebab-sebab lain terlebih dulu. Namun, dalam praktiknya terdapat suatu kasus PT. Bank Pundi Indonesia diakuisisi menjadi atas nama PT. Bank Pembangunan Daerah Banten.

Permasalahan yang timbul sehubungan dengan adanya pengambilalihan (Akuisisi) perusahaan PT. Bank Pundi Indonesia menjadi izin usaha atas nama PT. Bank Pembangunan Daerah Banten, bahwa sebelumnya PT. Bank Pundi Indonesia merupakan pemegang jaminan hak tanggungan atas sebidang tanah Hak Milik Nomor 6864/Kelurahan Sumbersari seluas $122 \mathrm{M}^{2}$ (seratus dua puluh dua meter persegi) sesuai dengan Sertifikat Hak Tanggungan Nomor : 820/2013 peringkat pertama serta perubahan Sertifikat Hak Tanggungan Nomor : 1018/2014 peringkat kedua, sehingga perubahan nama menimbulkan ketidakpastian hukum terhadap jaminan hak tanggungan tersebut. Padahal sebelumnya kepemilikan jaminan hak tanggungan/pemegang jaminan hak tanggungan adalah PT. Bank Pundi Indonesia. Bahwa seharusnya prosedur pemberian, pendaftaran, peralihan dan hapusnya hak tanggungan atas tanah beserta benda-benda yang berkaitan dengan tanah dapat dilakukan melalui proses penyerahan akan piutang-piutang atas nama dan kebendaan tak bertubuh lainnya, dilakukan dengan jalan membuat sebuah akta otentik atau akta di bawah tangan, dengan mana hak-hak atas kebendaan itu dilimpahkan kepada orang lain (cessie), perpindahan hak kreditur kepada seorang pihak ketiga yang membayar kepada kreditur, dapat terjadi karena persetujuan atau karena undang-undang (subrogasi) dan pewarisan atau sebab-sebab lainnya serta wajib dituangkan/dicantumkan dalam Rapat Umum Pemegang Saham (RUPS) Perseroan Terbatas tersebut.

Berdasarkan latar belakang tersebut di atas, maka tujuan penelitian ini untuk menganalisis persoalan-persoalan yang dirumuskan sebagai berikut: pertama

1Yudha Pandu, Himpunan Peraturan Perundang-undangan Jaminan Fidusia dan Hak Tanggungan, Indonesia Legal Center Publishing, Jakarta, 2008, hlm. 65-66.

David Prasetyo, Peralihan Pemegang Hak Tanggungan Atas Akuisisi Perseroan Terbatas. 
mengenai karakteristik peralihan hak dan kewajiban pada proses akuisisi perusahaan. Kedua, akibat hukum terhadap kedudukan pemegang hak tanggungan dan pemberi hak tanggungan pada proses akuisisi perusahaan.

\section{METODE PENELITIAN}

Penelitian hukum ini menggunakan metode penelitian normatif, yang bersumber dari bahan-bahan hukum primer dan sekunder. Bahan hukum primer terdiri dari perundang-undangan, catatan-catatan resmi, atau risalah dalam pembuatan perundang-undangan dan putusan hakim. Sedangkan, bahan hukum sekunder berupa semua publikasi tentang hukum yang bukan merupakan dokumen-dokumen resmi. Dalam tulisan ini, bahan hukum primer diperoleh dari Undang-Undang Dasar Negara Republik Indonesia Tahun 1945 dan peraturan perundang-undangan yang lain yang terkait, sedangkan bahan hukum sekunder berupa teks perihal keilmuan hukum yang relevan dengan bahasan dalam tulisan ini yang diperoleh dari buku, jurnal, makalah, dan sumber data elektronik.

Pengumpulan bahan hukum dilakukan melalui prosedur identifikasi dan inventarisasi terhadap bahan-bahan hukum primer dan sekunder secara kritis, diambil yang relevan dengan permasalah yang dibahas, kemudian dilakukan klasifikasi secara logis sistematis terhadap bahan-bahan hukum yang sudah dikumpulkan. Bahan hukum primer dan bahan hukum sekunder yang telah dikumpulkan tersebut disusun dan dibaca secara sistematis, kemudian dianalisis berdasarkan teori dan aturan-aturan hukum yang berkaitan dengan Hak Tanggungan dan Akuisisi serta dilakukan interpretasi terhadap aturan-aturan hukum yang terkait guna menemukan jawaban atas rumusan masalah yang dikemukakan.

\section{HASIL DAN PEMBAHASAN}

\section{Karakteristik Peralihan Hak Dan Kewajiban Pada Proses Akuisisi Perusahaan}

Akuisisi berasal dari kata kerja "acquire" yang berarti memperoleh, mengambil alih. Akuisisi dalam terminologi bisnis diartikan sebagai pengambilalihan kepemilikan atau pengendalian atas saham atau aset suatu perusahaan oleh perusahaan lain dan dalam peristiwa ini baik perusahaan pengambilalih atau yang diambil alih tetap eksis sebagai badan hukum yang terpisah. ${ }^{2}$ Dari pengertian di atas dapat ditarik kesimpulan akuisisi terjadi ketika perusahaan memperoleh aktiva produktif dari perusahaan lain dan mengintegrasikan aktiva-aktiva tersebut kedalam aktiva miliknya. Akuisisi juga dapat terjadi ketika suatu perusahaan memperoleh pengendalian operasi atau fasilitas produktif entitas lain dengan memiliki sejumlah besar saham. Dalam akuisisi tidak ada perusahaan yang bubar kedua perusahaan yang terlibat dalam akuisisi secara yuridis masih tetap berdiri dan beroperasi secara independen tetapi terjadi pengalihan pengendalian oleh pihak pengakuisisi. Fenomena akuisisi sebenarnya merupakan keputusan strategis dalam dunia bisnis. Rasionalisasi dalam keputusan akuisisi sering disebut sebagai upaya untuk memacu

2 Lukas Setia Atmaja. Manajemen Keuangan, Edisi Revisi, Yogyakarta, 2003, hlm. 435.

David Prasetyo, Peralihan Pemegang Hak Tanggungan Atas Akuisisi Perseroan Terbatas. 
perusahaan agar lebih sehat dan lebih efesiensi untuk mencapai sinergi. Menurut Suad dan Enny, Kondisi saling menguntungkan tersebut akan terjadi kalau dari peristiwa akuisisi atau merger tersebut diperoleh sinergi. Sinergi berarti bahwa nilai gabungan dari kedua perusahaan tersebut lebih besar dari penjumlahan masingmasing nilai perusahaan yang digabungkan. Sinergi dapat bersumber dari bebagai sebab, misalnya pemanfaatan manajemen, untuk beroperasi lebih ekonomis (operating economies of scale), untuk pertumbuhan yang lebih cepat, dan pemanfaatan penghematan pajak. ${ }^{3}$

Berdasarkan Undang-Undang Nomor 40 Tahun 2007 tentang Perseroan Terbatas menggunakan istilah penggabungan, peleburan, dan pengambilalihan. Sedangkan Peraturan Pemerintah mengenai Perbankan menggunakan istilah Merger, Konsolidasi, dan Akuisisi. Peraturan Badan Pengawas Pasar Modal dan Lembaga Keuangan Nomor IX.G.1 mengunakan istilah Penggabungan Usaha atau Peleburan Usaha Perusahaan Publik atau Emiten. Beberapa negara lain menggunakan istilah konsentrasi dan take over. Berdasarkan pengertian pengambilalihan perseroan terbatas sebagaimana dimaksud, maka dapat ditarik beberapa unsur yang melekat dalam pengambilalihan antara lain yaitu, Pengambilalihan adalah suatu perbuatan hukum; Pihak yang mengambilalih adalah orang atau badan hukum; Metode pengambilalihan dengan cara melakukan pengambilaihan saham; dan Pengambilalihan saham itu dapat mengakibatkan beralihnya pengendalian atas perseorangan terbatas tersebut.

Akuisisi pada Perseroan Terbatas mempunyai dampak yang signifikan terhadap Perusahaan. Peningkatan akan terjadi pada besarnya pendapatan, pengurangan biaya, penurunan atau pengecualian pengenaan pajak, dan pengurangan biaya modal kerja. Dengan kata lain akuisisi menjadi pilihan yang lebih memiliki prospek dibanding dengan pola penyelamatan lainnya.

Akuisisi pada Perseroan Terbuka diatur pada Peraturan Badan Pengawas Pasar Modal dan Lembaga Keuangan Nomor IX.E.2 dan Peraturan Badan Pengawas Pasar Modal dan Lembaga Keuangan Nomor IX.H.1. Dalam akuisisi ini, ada istilah yang bernama Transaksi Material. Transaksi material berdasarkan Angka 1 Huruf a Point 2 Peraturan Badan Pengawas Pasar Modal dan Lembaga Keuangan Nomor IX.E.2 tentang Transaksi Material dan Perubahan Kegiatan Usaha Utama adalah setiap a) penyertaan dalam badan usaha, proyek, dan/atau kegiatan usaha tertentu; b) pembelian, penjualan, pengalihan, tukar menukar aset atau segmen usaha; c) sewa menyewa aset; d) pinjam meminjam dana; e) menjaminkan aset; dan/atau f) memberikan jaminan perusahaan dengan nilai 20\% (dua puluh perseratus) atau lebih dari ekuitas Perusahaan, yang dilakukan dalam satu kali atau dalam suatu rangkaian transaksi untuk suatu tujuan atau kegiatan tertentu. Pengertian Akuisisi (pengambialihan) berdasarkan Peraturan Badan Pengawas Pasar Modal dan Lembaga Keuangan Nomor IX.H.1 Angka 1 Huruf d adalah tindakan, baik langsung maupun tidak langsung, yang mengakibatkan perubahan pengendali. Dimana pengertian Pengendali Perusahaan Terbuka, yang selanjutnya disebut Pengendali adalah pihak

3 Suad Husnan dan Enny Pujiasturi, Dasar-Dasar Manajemen Keuangan, Edisi 6. UPP-AMP YKPN, Yogyakarta, 2012, hlm. 396.

David Prasetyo, Peralihan Pemegang Hak Tanggungan Atas Akuisisi Perseroan Terbatas. 
yang memiliki saham lebih dari 50\% (lima perseratus) dari seluruh saham yang disetor penuh, atau Pihak yang mempunyai kemampuan untuk menentukan, baik langsung maupun tidak langsung, dengan cara apapun pengelolaan dan/atau kebijaksanaan Perusahaan Terbuka (Angka 1 Huruf c Peraturan Badan Pengawas Pasar Modal dan Lembaga Keuangan Nomor IX.H.1). Perbedaan prosedur akusisi pada Perseroan Tertutup dan Perseroan Terbuka terletak pada tahapan tambahan untuk Perseroan terbuka setelah terjadinya akuisisi, yaitu pernyataan kepada Bapepam (max. 1 hari kerja setelah terjadinya akuisisi), pengumuman telah terjadinya akuissi dalam 2 surat kabar, dan yang terpenting adalah melakukan penawaran tender wajib. Penawaran Tender Wajib adalah penawaran untuk membeli Perusahaan Terbuka yang wajib dilakukan oleh Pengendali baru (Angka 1 Huruf e Peraturan Badan Pengawas Pasar Modal dan Lembaga Keuangan Nomor IX.F.1). Pelaksanaannya adalah dengan cara pengumuman keterbukaan Informasi, Pelaksanaan dan Penyelesaian, dan Harga pembelian saham dalam penawaran Tender wajib.

Berdasarkan Pasal 125 Ayat (1) UUPT, pengambilalihan dilakukan dengan cara pengambilalihan saham yang telah dikeluarkan dan/atau akan dikeluarkan oleh Perseroan melalui Direksi Perseroan atau langsung berupa badan hukum atau orang perseorangan. Pengambilalihan saham yang dimaksud Pasal 125 Ayat (1) adalah pengambilalihan yang mengakibatkan beralihnya pengendalian terhadap Perseroan nantinya seperti yang dimasuk dalam Pasal 7 Angka 11 UUPT.

Proses akuisisi hanya mengubah status pemilik saham yaitu beralih dari pemegang saham perseroan terakuisisi kepada pemegang saham pengakuisisi. Jadi perubahan yang timbul bukan pada status perseroan tetapi pada pemegang saham pengkuisisi dan perusahaan terakuisisi tetap berdiri dan menjalankan semua kegiatan perseroan tersebut secara mandiri. ${ }^{4}$ Pelaksanaan Akuisisi dapat dilakukan perseroan atau langsung dari pemegang saham. Akuisisi saham dilakukan atas seluruh atau sebagian besar saham yang mengakibatkan beralihnya pengendalian terhadap perseroan tersebut. UUPT mensyaratkan perlindungan terhadap pihak karyawan, disamping perlindungan pihak-pihak lainnya, dalam hal terjadinya Merger, Akuisisi dan Konsolidasi.

Perubahan yang terjadi haruslah mendapatkan persetujuan dari Kemenkumham. Selain pemberitahuan atau permohonan dan persetujuan Kemenkumham direksi hasil peleburan juga wajib untuk mengumumkan hasil peleburan dari 1 (satu) surat kabar harian atau lebih dalam jangka waktu 30 (tiga puluh) hari sejak yanggal berlakunya peleburan. Bagi suatu perusahaan yang akan melakukan penggabungan, peleburan, dan Akuisisi (pengambilalihan) tidak perlu mendapatkan persetujuan dari Menteri Hukum dan Hak Asasi Manusia kecuali merubah Akuisisi disetujui yang mencakup satu atau lebih perubahan tersebut di atas. Dalam hal terjadi penggabungan, peleburan dan Akuisisi dengan perubahan

4 Abdul Moin, Merger, Akuisisi dan Divestaqsi, jilid Pertama, Ekonosia, Yogyakarta, 2004, hlm. 10.

David Prasetyo, Peralihan Pemegang Hak Tanggungan Atas Akuisisi Perseroan Terbatas. 
akuisisi disetujui yang demikian, penggabungan, peleburan dan Akuisisi baru mulai berlaku sejak tanggal persetujuan perubahan Anggaran Dasar oleh Menteri tersebut.

Terdapat tiga prosedur dasar yang tepat dilakukan perusahaan untuk mengambil alih perusahaan lain, pertama merger, istilah Merger sering digunakan untuk menunjukkan penggabungan dua perusahaan atau lebih, dan kemudian tinggal nama salah satu perusahaan yang bergabung. Sedangkan, Konsolidasi menunjukkan penggabungan dari dua perusahaan atau lebih, dan dari perusahaanperusahaan yang bergabung tersebut hilang, kemudian muncul nama baru dari perusahaan gabungan. Cara kedua adalah akuisisi saham, yaitu untuk mengambil alih perusahaan lain adalah membeli saham perusahaan tersebut, baik dibeli secara tunai, ataupun menggantinya dengan sekuritas lain (saham atau obligasi). Ketiga adalah Akuisisi Aset, yaitu suatu perusahaan dapat mengakuisisi perusahaan lain dengan jalan membeli aktiva perusahaan tersebut. Cara ini akan menghindarkan perusahaan dari kemungkinan memiliki pemegang saham minoritas, yang dapat terjadi pada peristiwa akuisisi saham. Akuisisi asets dilakukan dengan cara pemindahan hak kepemilikan aktiva-aktiva yang dibeli.

Badan hukum merupakan subjek hukum buatan manusia berdasarkan hukum yang berlaku. Agar dapat berbuat menurut hukum, maka badan hukum diurus oleh pengurus yang ditetapkan dalam anggaran dasarnya, sebagai yang berwenang mewakili badan hukum. Artinya, perbuatan pengurus adalah perbuatan badan hukum. Perbuatan pengurus tersebut selalu mengatasnamakan badan hukum, bukan atas nama pribadi pengurus. Segala kewajiban yang timbul dari perbuatan pengurus adalah kewajiban badan hukum, yang dibebankan pada harta kekayaan badan hukum. Sebaliknya pula, segala hak yang diperoleh dari perbuatan pengurus adalah hak badan hukum yang menjadi kekayaan badan hukum. ${ }^{5}$ Perusahaan badan hukum merupakan subjek hukum yang diurus dan dikelola oleh pengurus. Yang termasuk dalam perusahaan badan hukum yang dimiliki oleh pihak swasta dapat kita lihat antara lain adalah Perseroan Terbatas (PT) dan Badan Usaha Koperasi. Sedangkan, yang dimiliki oleh negara yaitu perusahaan umum (perum) dan perusahaan perseroan. ${ }^{6}$ Perseroan Terbatas (PT) adalah merupakan suatu persekutuan yang berbentuk badan hukum yang dipakai sebagai terjemahan dari Naamloooze Vennootschap (NV). Istilah terbatas di dalam PT tertuju pada tanggung jawab para persero atau pemegang saham yang luasnya hanya terbatas pada jumlah nominal nilai dari semua saham-saham yang dimiliki. ${ }^{7}$

Bentuk perusahaan bukan badan hukum Perusahaan bukan badan hukum adalah perusahaan swasta yang didirikan dan dimiliki oleh beberapa orang pengusaha secara kerja sama. Bentuk perusahaan ini merupakan perusahaan persekutuan yang dapat menjalankan usaha dalam bidang perekonomian, yaitu perindustrian, perdagangan, dan perjasaan. Perusahaan tidak berbadan hukum

12 Abdulkadir Muhammad, Hukum Perusahaan Indonesia, Cetakan Keempat Revisi, Bandung: Citra Aditya Bakti. 2002. hlm. 103.

$13 \mathrm{Ibid}$.

14 R.T. Sutantya dkk, Hukum Koperasi Indonesia, Raja Grafindo Persada, Jakarta, 1991, hlm. 39.

David Prasetyo, Peralihan Pemegang Hak Tanggungan Atas Akuisisi Perseroan Terbatas. 
dapat berupa perusahaan perseorangan dan perusahaan persekutuan, dan hanya dimiliki oleh pihak swasta. ${ }^{8}$ Dalam mendirikan perusahaan persekutuan bukan badan hukum didirikan oleh lebih dari satu orang, maka perlu diadakan perjanjian lebih dahulu antara para sekutu pendiri. Jika sudah tercapai persetujuan mengenai isi perjanjian itu, barulah kemudian dibuat rancangan anggaran dasar kemudian dituangkan dalam akta pendirian yang dibuat di muka notaris. ${ }^{9}$ Agar perjanjian yang dibuat itu sah menurut hukum, harus dipenuhi persyaratan pokok pasal 1320 KUHPerdata, yaitu kesepakatan antara kedua belah pihak, cakap melakukan perbuatan hukum, adanya objek tertentu, dan adanya kausa yang halal. Yang termasuk dalam perusahaan bukan badan hukum dapat kita lihat pada firma dan persekutuan komanditer (CV).

Selanjutnya mengenai modal, pengertian modal tidak diatur dalam UndangUndang Nomor 40 Tahun 2007. Pada umumnya modal memiliki arti yang berbeda antara ilmu ekonomi dan ilmu hukum, sehingga dapat ditarik secara umum bahwa modal adalah sesuatu yang diperoleh perseroan dalam bentuk uang melalui penerbitan sahan (issuance of shares) untuk melancarkan kegiatan usaha dan bisnisnya sesuai dengan yang ditentukan dalam anggaran dasar perseroan. Pengelompokkan jenis modal perseroan terbatas dalam Undang-Undang Nomor 40 Tahun 2007 terbagi menjadi 3 jenis yaitu modal dasar, modal ditempatkan, dan modal disetor. Modal dalam perseroan terbatas merupakan syarat materiil dalam pembentukannya, sedangkan pembuatan akta pendirian perseroan melalui akta notaris adalah syarat formiil.

1) Modal Dasar (authorized capital)

Adalah jumlah maksimum modal yang disebutkan dalam akta pendirian perseroan terbatas, berdasarkan kesepakatan para pihak yang mendirikan. ${ }^{10}$ Sesuai Pasal 31 Ayat (1) Undang-Undang Nomor 40 Tahun 2007, modal dasar perseroan terbagi atas seluruh nominal saham, yaitu jumlah saham yang dikeluarkan perseran dengan menetapkan nilai setiap saham. Maksud jumlah maksimum dalam pengertian modal dasar adalah modal maksimal yang harus disetor pemegang saham ke kas perseroan dan atas penyetoran tersebut perusahaan akan mengeluarkan saham. ${ }^{11}$

2) Modal Ditempatkan (geplaasts kapitaal, subscribed capital, issued capital)

Adalah modal yang disangupi oleh pemegang saham untuk dimasukkan ke dalam kas perusahaan dari jumlah modal dasar yang diambil bagian oleh pemegang saham. ${ }^{12}$ Arti dari "diambil bagian" dalam definisi tersebut adalah karena tidak semua modal dasar harus dikeluarkan dan diambil oleh pendiri saat

15 Abdulkadir Muhammad, Hukum Perusahaan Indonesia, Cetakan Keempat Revisi, Bandung: Citra Aditya Bakti. 2002. hlm. 84

16 Ibid., hlm. 86.

17 H.M.N. Purwosutjipto, Pengertian Pokok Hukum Dagang Indonesia 2, Penerbit Djambatan, Jakarta, 1988, hlm. 103.

18 Philip Lipton dan Abraham Herzberg, Undertanding of Company Law, Australia, Corporate Education Services, 1995, hlm. 187.

19 Soekardono, Hukum Dagang Indonesia, Jilid I, Bagian Kedua, Rajawali, Jakarta, 1985, hlm. 167.

David Prasetyo, Peralihan Pemegang Hak Tanggungan Atas Akuisisi Perseroan Terbatas. 
perseroan dibentuk. ${ }^{13}$ Modal dalam hal ini sangat penting karena merupakan sumber dana (source of funds) jika ada tuntutan dari kreditor. Menurut Pasal 33 Ayat (1) Undang-Undang Nomor 40 Tahun 2007, modal dasar perseroan ditempatkan atau diambil bagian minimal 25\% dari modal dasar. Sehingga, masih dimungkinkan tersisa sejumlah modal dasar yang dapat diambil sebagian oleh pemegang saham yang disebut saham dalam portefel. ${ }^{14}$

3) Modal Disetor (gestort kapitaal, paid up capital)

Adalah modal sesungguhnya yang dimasukkan oleh pemegang saham ke kas perseroan untuk melakukan kegiatan usaha dan jumlahnya dapat dilihat pada neraca perseroan. Arti dari neraca perseroan adalah daftar posisi keuangan perusahaan yang menunjukkan keadaan aktiva, hutang dan modal pada tanggal tertentu yang disusun secara sistematis. ${ }^{15}$ Modal disetor dapat dijadikan sebagai jaminan bagi kreditor atau pemenuhan tanggungjawab perseroan pada pihak ketiga apabila perseroan mengalami kepailitan. Menurut Pasal 33 Undang-Undang Nomor 40 Tahun 2007, jumlah modal yang disetor minimal $25 \%$ dari modal usaha dan penyetoran modal yang disetor tidak dilakukan dengan cara mengangsur. Dilanjutkan bentuk modal disetor dapat dilihat dalam Pasal 34 Undang-Undang Nomor 40 Tahun 2007 meliputi, secara tunai atau dalam bentuk lain. Maksud dari kata dalam bentuk lain adalah dapat berupa benda bergerak maupun tidak bergerak. Penyetoran benda bergerak harus dilakukan sesuai dengan harga pasar yang ditawarkan pada umumnya yang penilainnya dilakukan oleh perusahaan penilai (appraisal company). Sedangkan, penyetoran modal dalam bentuk tidak bergerak harus diumumkan pada satu surat kabar dengan jangka waktu 14 hari setelah penandatanganan akta pendirian.

1. Peralihan Hak dan Kewajiban dalam Proses Akuisisi Perusahaan

Adapun peralihan hak dan kewajiban dalam proses akuisisi perusahaan khususnya pengambilalihan saham perseroan terbatas secara langsung dari Pemegang saham, yang antara lain sebagai berikut:

1. Akuisisi saham wajib memperhatikan ketentuan pemindahan hak atas saham dalam Anggaran Dasar, serta mendapat persetujuan rapat Umum Pemegang Saham (RUPS). RUPS wajib dilakukan paling lambat 30 tiga puluh) hari setelah pengumuman, (Pasal 126 Ayat (6) dan (7) UUPT).

2. Direksi perseroan yang akan melakukan akuisisi wajib mengumumkan ringkasan rancangan paling sedikit dalam 1 (satu) surat kabar dan mengumumkan secara tertulis kepada karyawan dari perseroan dalam waktu paling lambat 30 hari sebelum pemanggilan RUPS, (Pasal 127 Ayat (8) UUPT).

3. Kreditor dapat mengajukan keberatan kepada perseroan dalam waktu paling lambat 14 hari setelah pengumuman mengenai akuisisi sesuai dengan rancangan dimaksud. Apabila kreditor tidak mengajukan keberatan dlm jangka waktu

${ }^{20}$ Marzuki Usman et.al., ABC Pasar Modal Indonesia, Institut Bankir Indonesia, Jakarta, 1994, hlm. 71.

21 Munir Fuady, Hukum Perusahaan dalam Paradigma Hukum Bisnis, Citra Aditya Bakti, Bandung, 2008, hlm. 25.

22 Slamet B. Noor, Kamus Akuntansi, Majalah Keuangan, Jakarta, 1988, hlm. 245.

David Prasetyo, Peralihan Pemegang Hak Tanggungan Atas Akuisisi Perseroan Terbatas. 
tersebut maka kreditor dianggap menyetujui akuisisi. dalam hal kebeartan dari kreditor sampai dengan tanggal diselenggarakannya RUPS tidak dapat diselesaikan oleh Direksi perseroan maka keberatan tersebut harus disampaikan dalam RUPS guna mendapat penyelesaian. Sebelum keberatan ini diselesaikan maka akuisisi tidak dapat dilaksanakan (Pasal 127 Ayat (2), (3), (5), (6), dan (7) UUPT.

4. Akta pemindahan hak atas saham wajib dinyatakan dengan akta notaris dan dalam bahasa Indonesia (Pasal 128 Ayat (2) UUPT).

5. Salinan dari kata pemindahan hak atas saham wajib dilampirkan pada penyampaian pemberitahuan kepada Menteri Hukum dan Hak Asasi Manusia tentang perubahan Struktur Pemegang Saham Perseroan (Pasal 131 Ayat (2) UUPT).

6. Direksi perseroan wajib mengumumkan hasil akuisisi dalam 1 surat kabar atau lebih dalam jangka waktu paling lambat 30 hari sejak tanggal pemberitahuan kepada Menteri Hukum dan Hak Asasi Manusia ataus ejak tanggal persetujuan perubahan Anggaran Dasar oleh Menteri Hukum dan Hak Asasi Manusia (Pasal 133 Ayat (2) UUPT).

Proses akuisisi hanya mengubah status pemilik saham yaitu beralih dari pemegang saham perseroan terakuisisi kepada pemegang saham pengakuisisi. Jadi perubahan yang timbul bukan pada status perseroan tetapi pada pemegang saham pengkuisisi dan perusahaan terakuisisi tetap berdiri dan menjalankan semua kegiatan perseroan tersebut secara mandiri. Berdasarkan ketentuan Pasal 126 Undang-Undang Perseroan Terbatas, mensyaratkan adanya perlindungan terhadap pihak karyawan dan perlindungan pihak lainnya, dalam hal terjadinya merger, akuisisi dan konsolidasi, yang menyatakan bahwa:

1. Perbuatan hukum penggabungan, peleburan, pengambilalihan atau pemisahan wajib memperhatikan kepentingan Perseroan, pemegang saham minoritas, karyawan perseroan, memperhatikan kepentingan Kreditor dan mitra usaha lainnya dari perseroan dan memperhatikan kepentingan Masyarakat dan persaingan sehat dalam melakukan usaha.

2. Pemegang saham yang tidak setuju terhadap keputusan RUPS mengenai penggabungan, peleburan, pengambilalihan atau pemisahan sebagaimana dimaksud pada ayat (1) hanya boleh menggunakan haknya sebagaimana dimaksud dalam Pasal 62.

3. Pelaksanaan hak sebagaimana dimaksud pada Ayat (2) tidak menghentikan proses pelaksanaan penggabungan, peleburan, pengambilalihan atau pemisahan.

\section{Akibat Hukum Terhadap Kedudukan Pemegang Hak Tanggungan Dan Pemberi Hak Tanggungan Pada Proses Akuisisi Perusahaan}

1. Hak dan Kewajiban, serta Perlindungan Hukum Bagi Kreditur Sebagai Pemegang Hak Tanggungan

a. Kedudukan Kreditur Sebagai Pemegang Hak Tanggungan

Berdasarkan BW ada 3 (tiga) istilah kreditur yang dikenal, yaitu sebagai berikut :

1. Kreditur konkuren.

David Prasetyo, Peralihan Pemegang Hak Tanggungan Atas Akuisisi Perseroan Terbatas. 
Kreditur konkuren diatur dalam Pasal 1132 BW. Kreditur konkuren adalah para kreditur dengan hak pai Passau dan pro rata, artinya para kreditur secara bersama-sama memperoleh pelunasan (tanpa ada yang didahulukan) yang dihitung berdasarkan pada besarnya piutang masing-masing dibandingkan terhadap piutang mereka secara keseluruhan, terhadap seluruh harta kekayaan debitur tersebut. Dengan demikian, para kreditur konkuren mempunyai kedudukan yang sama atas pelunasan utang dari harta debitur tanpa ada yang didahulukan.

2. Kreditur preferen (yang diistimewakan).

Yaitu kreditur yang oleh undang-undang, semata-mata karena sifat piutangnya, mendapatkan pelunasan terlebih dahulu. Kreditur preferen merupakan kreditur yang mempunyai hak istimewa, yaitu suatu hak yang oleh undangundang diberikan kepada seseorang berpiutang sehingga tingkatnya lebih tinggi dari pada orang berpiutang lainnya, semata-mata berdasarkan sifat piutangnya. Untuk megetahui piutang-piutang mana yang diistimewakan dapat dilihat dalam Pasal 1139 dan Pasal 1149 BW.

3. Kreditur separatis

Yaitu kreditur pemegang hak jaminan kebendaan in rem, yang dalam BW disebut dengan nama gadai dan hipotek. Hak penting yang dipunyai kreditur separatis adalah hak untuk dapat kewenangan sendiri menjual/ mengeksekusi objek agunan, tanpa putusan pengadilan (parate eksekusi). Hak tersebut untuk gadai, hipotek dan jaminan fidusia.

b. Hak dan Kewajiban Kreditur

Kreditur adalah orang yang memiliki piutang. Dalam hal ini orang yang memiliki piutang dapat berupa orang orang atau badan hukum, Bank, Lembaga Pembiayaan, Penggadaian atau Lembaga Penjamin Lainnya. Dalam hal ini hak maupun kewajiban dari kreditur adalah memberikan pinjaman kepada seorang debitur berupa uang atau mungkin modal untuk sebuah usaha dari debitur atau penggunaan lain yang akan digunakan dari pinjaman uang tersebut. Dalam hal ini hak kreditur mempunyai kewajiban membantu siapa saja yang akan melakukan pinjaman. Dan sebagai gantinya kreditur berhak menahan barang atau benda berharga milik debitur sebagai jaminan kepada kreditur untuk melakukan pelunasan hutangnya. Dalam hal lembaga peminjaman adalah Gadai maka benda yang berharga sebagai jaminannya seperti emas. Dalam hal jaminan fidusia yang merupakan perjanjian khusus yang diadakan antara debitur dan kreditur untuk memperjanjikan hal-hal sebagai berikut :

1. Jaminan yang bersifat kebendaan, yaitu adanya benda tertentu yang dijadikan agunan.

2. Jaminan yang bersifat perorangan atau personlijk yaitu adanya orang tertentu yang sanggup membayar atau memenuhi prestasi debitur jika debitur cidera janji. ${ }^{16}$

Berkaitan dengan hubungan fidusia, jelas bahwa ada keterkaitan erat antara para pihak yaitu adanya hubungan kepercayaan atas dasar itikad baik. Hubungan kepercayaan tersebut sekarang bukan semata-mata atas dasar kehendak kedua belah

${ }^{23}$ Andreas Albertus, Hukum Fidusia, Penerbit Selaras, Malang. 2010, hlm. 31.

David Prasetyo, Peralihan Pemegang Hak Tanggungan Atas Akuisisi Perseroan Terbatas. 
pihak saja, namun didasarkan atas aturan hukum yang mengikat. Jaminan bersifat kebendaan dilembagakan dalam bentuk Hipotek, Hak Tanggungan, Fidusia, Gadai, dan Undang-Undang Sistem Resi Gudang.

Secara garis besar, jaminan diatur dalam peraturan perundang-undangan Republik Indonesia mempunyai asas sebagai berikut :

1. Hak jaminan memberikan kedudukan yang didahulukan bagi kreditur pemegang hak jaminan terhadap para kreditur lainnya.

2. Hak jaminan merupakan hak assessoir terhadap perjanjian pokok yang dijamin dengan perjanjian tersebut. Perjanjian pokok yang dijamin itu adalah perjanjian utang-piutang antara kreditur dan debitur, artinya apabila perjanjian pokoknya berakhir, maka perjanjian hak jaminan demi hukum berakhir pula.

3. Hak jaminan memberikan hak separatis bagi kreditur pemegang hak jaminan itu. Artinya, benda yang dibebani dengan hak jaminan itu bukan merupakan harta pailit dalam hal debitur dinyatakan pailit oleh pengadilan.

4. Hak jaminan merupakan hak kebendaan atas real right artinya hak jaminan itu akan selalu melekat di atas benda tersebut atau selalu mengikuti benda tersebut kepada siapapun juga benda beralih kepemilikannya atau droit de suite.

5. Kreditur pemegang hak jaminan mempunyai kewenangan penuh untuk melakukan eksekusi atas hak jaminannya. Artinya, kreditur pemegang hak jaminan itu berwenang untuk menjual sendiri, baik berdasarkan penetapan pengadilan maupun berdasarkan kekuasaan yang diberikan undang-undang, benda yang dibebani dengan hak jaminan tersebut dan mengambil hasil penjualannya untuk melunasi piutangnya kepada debitur.

6. Oleh karena merupakan hak kebendaan, maka hak jaminan berlaku bagi pihak ketiga, terhadap hak jaminan berlaku asas publisitas. Artinya, hak jaminan tersebut harus didaftarkan di kantor pendaftaran hak jaminan yang bersangkutan. ${ }^{17}$

Berdasarkan uraian tersebut di atas, bahwa hak dan kewajiban kreditur adalah sebagai lembaga jaminan atau peminjaman untuk memberikan bantuan dana terhadap debitur, dimana hal tersebut di daftarkan kepada lembaga penjamin kebendaan yang bersangkutan, dan dalam hal ini kreditur berhak menerima jaminan dari seorang debitur, dan jika tidak terjadi pelunasan hutang oleh debitur maka kreditur berhak mengeksekusi barang jaminan dengan menjual atau menyatakan debitur tersebut pailit karena tidak mampu membayar hutang.

c. Perlindungan Hukum Bagi Kreditur

Perlindungan hukum terhadap kreditur secara umum diatur dalam BW, Pasal 1131 dan 1132 dan Undang-Undang Nomor 42 Tahun 1999 tentang Jaminan Fidusia. Pasal 1131 BW menyebutkan, "segala kebendaan, baik yang sudah ada maupun yang baru aka nada dikemudian hari, menjadi tanggungan untuk segala perikatan perseorangan." Pasal tersebut dapat diartikan, sejak seseorang mengikatkan diri pada suatu perjanjian maka sejak itu semua harta kekayaan baik yang sudah ada maupun yang baru aka nada di kemudian hari menjadi tanggungan untuk segala

${ }^{24}$ Ibid., hlm. 32-33.

David Prasetyo, Peralihan Pemegang Hak Tanggungan Atas Akuisisi Perseroan Terbatas. 
perikatannya. Berikutnya Pasal 1132 BW menyebutkan "kebendaan tersebut menjadi jaminan bersama-sama bagi semua orang yang mengutangkan kepadanya, pendapatan penjualan benda-benda itu dibagi-bagi menurut keseimbangan, yaitu menurut besar kecilnya piutang masing-masing, kecuali apabila diantara para berpiutang itu ada alasan-alasan yang sah didahulukan." Pasal ini menjelaskan bahwa harta kekayaan debitur menjadi jaminan bagi para krediturnya. Hasil penjualan dibagi menurut imbangan masing-masing kecuali ada hak untuk didahulukan.

2. Hak dan Kewajiban, serta Perlindungan Hukum Bagi Debitur Sebagai Pemberi Hak Tanggungan

a. Kedudukan Debitur Sebagai Pemberi Hak Tanggungan

Pengertian debitur menurut Aliminsyah dan Padji, menyatakan bahwa "Debitur adalah pihak yang menerima kredit atau pinjaman".18 Menurut Rahmat Firdaus dan Maya Arianti, pengertian Debitur adalah pihak yang membutuhkan atau meminjam uang, barang dan jasa. ${ }^{19}$ Menurut Riduan Tobink dan Bill Nikholaus, Debitur adalah orang atau badan usaha yang memilki hutang kepada bank atau lembaga pembiayaan lainnya karena perjanjian atau undang-undang. ${ }^{20}$ Sedangkan menurut Johar Arifin dan Muhammad Fakhrudin menyatakan bahwa Debitur adalah nasabah yang memperoleh fasilitas dari bank tersebut. ${ }^{21}$ Dari penjelasan tersebut dapat disimpulkan bahwa debitur adalah pihak yang membutuhkan dana dan memenuhi syarat sebagai nasabah salah satu lembaga keuangan dan memperoleh fasilitas dari lembaga keuangan atau bank tersebut dalam bentuk kredit atau pinjaman. Berdasarkan Pasal 1 Angka 3 Undang-Undang Nomor 37 Tahun 2004 tentang Kepailitan dan Penundaan Kewajiban Pembayaran Utang, yang menyatakan bahwa Debitur adalah orang yang mempunyai utang karena perjanjian atau undang-undang yang pelunasannya dapat ditagih di muka pengadilan.

b. Hak dan Kewajiban Debitur

Pengertian mengenai debitur telah dipaparkan diatas, yaitu seseorang yang memiliki hutang. Dalam hal mengenai hak dan kewajiban seorang debitur merupakan kebalikan dari hak dan kewajiban kreditur. Karena seorang debitur adalah orang yang memiliki hutang, maka kewajibannya adalah membayar lunas hutangnya kepada kreditur. Selain itu debitur juga mempunyai kewajiban berupa memberikan jaminan kepada kreditur sebagai jaminan hutangnya, seketika debitur membayar lunas maka debitur berhak menerima kembali barang yang dijaminkan sebagai agunan peminjaman kepada pihak kreditur. Dalam hal ini orang dikatakan sebagai debitur adalah orang atau perorangan yaitu dalam hal ini baik laki-laki maupun

25 Aliminsyah dan Padji, Kamus Istilah Keuangan dan Perbankan, Penebar Swadaya, Jakarta, 2003, hlm. 98.

${ }^{26}$ Rahmad Firdaus dan Maya Arianti, Manajemen Perkreditan Bank, Alfabeta, Bandung, 2004, hlm. 3.

27 Riduan Tobink dan Bill Nikholaus, "Kamus Istilah Perbankan", Atalya Rileni Sudeco, Jakarta, 2003, hlm. 118.

28 Johar Arifin dan Muhammad Fakhrudin, Kamus Pasar Modal, Akuntansi, Keuangan dan Perbankan, 2001, hlm. 101.

David Prasetyo, Peralihan Pemegang Hak Tanggungan Atas Akuisisi Perseroan Terbatas. 
perempuan dapat dinyatakan pailit oleh pengadilan jika tidak mampu membayar hutang kepada satu atau lebih kreditur. Perserikatan-perserikatan atau perkumpulan-perkumpulan yang bukan badan hukum seperti maatschap, firma dan perkumpulan komanditer, perseroanperseroan atau perkumpulan-perkumpulan yang berbadan hukum seperti Perseroan Terbatas (PT), Koperasi dan Yayasan.

Berdasarkan Ketentuan Umum Bab I Pasal 1 Angka 11 Undang-Undang Nomor 37 Tahun 2004 Tentang Kepailitan Dan Penundaan Kewajiban Pembayaran Utang menyebutkan bahwa Setiap Orang adalah orang perseorangan atau korporasi termasuk korporasi yang berbentuk badan hukum maupun yang bukan badan hukum dalam likuidasi. Melalui ketentuan ini jelas bahwa setiap orang baik orang perseorangan atau korporasi termasuk korporasi yang berbentuk badan hukum maupun yang bukan badan hukum dalam likuidasi dapat mengajukan permohonan pailit dan dapat diajukan pailit, dalam arti bisa menjadi kreditur atau debitur.

c. Perlindungan Hukum Bagi Debitur

Perlindungan Hukum Debitur berdasarkan Undang-Undang Nomor 8 Tahun 1999 tentang Perlindungan Konsumen dan Perlindungan Penentuan Nilai Limit Lelang Jaminan Hak Tanggungan Konsumen merupakan salah satu pelaku kegiatan perekonomian dalam suatu Negara. Berdasarkan ketentuan Pasal 1 butir 1 UndangUndang Perlindungan Konsumen, Perlindungan Konsumen adalah segala upaya yang menjamin adanya kepastian hukum untuk memberi perlindungan kepada konsumen. Dalam Pasal 2 yang berbunyi bahwa perlindungan konsumen berdasarkan manfaat, keadilan, keseimbangan, keamanan dan keselamatan konsumen, serta kepastian hukum.

3. Kedudukan Kreditur dan Debitur dalam Proses Akuisisi Perusahaan

Pada dasarnya peralihan kepemilikan, tidak mengubah perjanjian antara perusahaan yang diakuisisi dengan pihak ketiga. Hal demikian merupakan implementasi dari asas separate entity yang diatur dalam ketentuan Undang-Undang Perseroan Terbatas, yang berbunyi bahwa Pemegang saham Perseroan tidak bertanggungjawab secara pribadi atas perikatan yang dibuat atas nama Perseroan dan tidak bertanggungjawab atas kerugian Perseroan melebihi saham yang dimiliki. Maksud dari ketentuan tersebut adalah kewajiban perusahaan atas setiap perikatan yang pernah dan atau yang telah dilakukan tidak merujuk pada siapa yang memilikinya saat ini, kecuali telah disepakati sebaliknya antara para pihak dalam perjanjian tersebut.

Pengambillalihan suatu perusahaan khususnya akan melakukan akuisisi guna dapat mengidentifikasikan perlindungan hukum, kedudukan para pihak dan kepentingan pihak ketiga, perlu dipastikan apakah akuisisi yang akan dilakukan dari perusahaan induk ke perusahaan anak terhadap perjanjian yang mensyaratkan kondisi-kondisi tertentu yang harus terjadi pasca pengambilalihan. Akuisisi biasanya dituangkan dalam Condional Sale-Purchase Agreement yang biasanya ditandatangani antara pemegang saham lama dengan pemegang saham baru. Perjanjian tersebut menjadi syarat awal dilakukannya pengambilalihan, terutama dalam hal pembentukan suatu perusahaan grup, agar terdapat penyamarataan perlakuan dan kinerja, sehingga memastikan keberlangsungan perusahaan dengan baik.

David Prasetyo, Peralihan Pemegang Hak Tanggungan Atas Akuisisi Perseroan Terbatas. 
Condional Sale-Purchase Agreement tidak serta merta memberikan dampak bagi kreditur. Perusahaan tetap harus tunduk dan memperhatikan serta mengutamakan kepentingan pihak ketiga, terutama kreditur, sekalipun perusahaan tersebut berubah kebijakannya karena diakuisisi atau kebijakan tersebut perintah dari pemerintah, tetap harus memperhitungkan hak, kewajiban dan tanggungjawab dari kreditur sebagaimana yang diatur dalam ketentuan Pasal 126 Ayat (1) Undang-Undang Perseroan Terbatas. Sebagai bentuk perlindungan kepentingan kreditur, maka dimungkinkan pengajuan keberatan oleh kreditur kepada perseroan yang diambil alih, dengan ketentuan keberatan diajukan dalam jangka waktu 14 (empat belas) hari setelah pengumuman dalam surat kabar, apabila dalam waktu tersebut tidak ada keberatan dianggap kreditur menyetujuinya. Jika direksi tidak menyelesaikan keberatan yang sudah diajukan kreditur, maka keberatan sedemikian harus disampaikan direksi dalam RUPS dan RUPS yang kan bertindak dalam penyelesaian dan apabila keberatan kreditur tidak diselesaikan, maka pengambilalihan tidak dapat dilaksanakan.

4...Akibat Hukum Adanya Proses Akuisisi Pada Perusahaan

Pengambilalihan atau Akuisisi Pada Perseroan Terbatas ternyata juga dapat memberikan akibat hukum yang mempengaruhi perusahaan. Akibat hukum yang dimaksud dalam perusahaan tersebut adalah akibat hukum baik secara kelembagaan yaitu pemegang Saham, karyawan, maupun pihak ketiga. Berikut penjelasan terkait akibat-akibat hukum dalam proses akuisisi pada perusahaan :

1. Akibat Yang Timbul Terhadap Perseroan Secara Kelembagaan

a. Internal

Yang dimaksud dengan Internal secara Kelembagaan dalam Perseroan Terbatas adalah bagian lingkungan yang ada dalam organisasi yang mempunyai kendali dalam menjalankan organisasi dan pada umumnya mempunyai implikasi khusus dalam mengelola organisasi tersbut. ${ }^{22}$ Organ Internal dalam Perseroan Terbatas yang terdiri dari Pemegang Saham, Karyawan, Direksi, Komisaris, dan Manajemen Perseroan. Organ internal ini sangat berpengaruh pada perusahaan, dimana organ internal yang membantu pertumbuhan perusahaan dengan cara memperbaiki serta memajukan kegiatan perusahaan, misalnya dengan adanya perbaikan atau pembaharuan produk pada perusahaan. ${ }^{23}$ Akibat Pengambilalihan atau Akuisisi perseroan terbatas terhadap Internal Perseroan Terbatas dalam arti bahwa Perseroan melakukan Akuisisi ini dengan tujuan untuk menambah sinergi, memperluas pangsa pasar, melindungi pasar, memperkuat bisnis inti. ${ }^{24}$

b. Eksternal

29 Rowland Bismark Fernando Pasaribu, Manajemen Strategi Lingkungan Internal Organisasi, Universitas Gunadharma, 2015, hlm.16.

30 Fuji Jaya Lesmana, "Perbedaan Kinerja Keuangan dan Abnormal Return Sebelum dan Sesudah Akuisisi di BEr”, Trikonomika, Volume 11,No.2, Desember 2012, hal.196, ISSN 1411-514X, 2012.

31 Munir Fuady, Hukum Tentang Akuisisi, Take Over, dan LBO, Citra Aditya, Bandung, 2014, hlm. 14.

David Prasetyo, Peralihan Pemegang Hak Tanggungan Atas Akuisisi Perseroan Terbatas. 
Yang dimaksud dengan eksternal perusahaan adalah anak perusahaan dari perseroan terbatas yang akan diambil alih. Akibat pengambilalihan Perseroan Terbatas terhadap perseroan secara eksternal, sebenarnya tidak terlalu terasa, karena dalam pengambilalihan perseroan sama sekali tidak mengubah status hukum atau keberadaan anak perusahaan pada perusahaan induk. Dalam pengambilalihan atau Akuisisi yang berubah hanya status pemegang sahamnya saja, dimana perusahaan dikendalikan oleh pemegang saham yang baru, yang dimaksud dengan pemegang saham disini adalah pemegang saham mayoritas. Pasal 84 Ayat (2) Huruf b UUPT, menyebutkan bahwa saham induk perseroan dikuasai oleh perusahaannya secara langsung atau tidak langsung. Dari pernyataan tersebut dapat diambil kesimpulan bahwa apabila terjadi akuisisi atau pengambilalihan, maka pemegang saham yang baru mempunyai tanggung jawab atas bisnis anak perusahaan. Dalam hal ini bisa dilakukan dengan membuat kontrak secara personal. ${ }^{25}$

1. Akibat Pengambilalihan Perseroan Terbatas Terhadap Pihak-Pihak Tertentu

Akibat hukum pengambilalihan Perseroan Terbatas terhadap Pihak-Pihak tertentu ini, terutama adalah terhadap pihak ketiga atau kreditur dari perseroan terbatas yang diakuisisi. Dalam praktek yang terjadi selama ini, status piutang kreditur pada perseroan terbatas yang di akuisisi menjadi tanggung jawab pemegang Saham yang baru. Sebagaimana yang dijelaskan dalam ketentuan Pasal 126 Ayat (1) Huruf b UUPT, menyebutkan bahwa perbuatan hukum pengambilalihan harus memperhatikan kepentingan kreditor dan mitra usaha lainnya dalam Perseroan. Ketentuan tersebut kemudian diperjelas dalam penjelasannya yaitu pengambilalihan tidak dapat dilaksanakan apabila merugikan pihak-pihak tertentu termasuk kreditur. Untuk menghindari kerugian terhadap kreditur, maka pengambilalihan harus berdasarkan keputusan RUPS. Di dalam RUPS, pihak yang akan mengambil alih maupun yang akan diambil alih menyampaikan maksudnya masing-masing. Maksud itu disampaikan kepada Direksi yang bersangkutan. Untuk Direksi harus menyusun rancangan pengambilalihan, yang didalam rancangan Pengambilalihan tersebut sekurang-kurangnya memuat laporan keuangan. Laporan keuangan tersebut diatur dalam Pasal 66 Ayat (2) Huruf a UUPT, yaitu Laporan keuangan yang terdiri atas sekurang-kurangnya neraca akhir tahun buku yang baru lampau dalam perbandingan dengan tahun buku sebelumnya, laporan laba rugi dari tahun buku yang bersangkutan, laporan arus kas, dan laporan perubahan ekuitas, serta catatan atas laporan keuangan tersebut.

Direksi pengambilalihan harus mencantumkan klausula "cara penyelesaian hak dan kewajiban perseroan terhadap pihak ketiga". Pada dasarnya sehubungan dengan kreditur dari perusahaan yang akan diakuisisi, pada prakteknya utang piutang tersebut antara perusahaan dan kreditur dapat kemudian dikonversikan terhadap harga jual Saham perseroan. Dalam hal ini, perseroan dapat melakukan perundingan dengan pihak yang akan mengambil alih untuk kemudian memasukkan hutang perseroan menjadi tanggung jawab pihak pembeli.

32 Gatot Supramono, Perbankan dan Masalah Kredit, Rineka Cipta, Jakarta, 2009, hlm. 91.

David Prasetyo, Peralihan Pemegang Hak Tanggungan Atas Akuisisi Perseroan Terbatas. 
Pemberian perlindungan terhadap kreditur, sebelum melakukan akuisisi adanya kewajiban Direksi perseroan untuk memberitahukan rancangan pengambilalihan dalam 1 (satu) surat kabar yang diumumkan secara tertulis kepada karyawan, dan juga kepada pihak yang berkepentingan, salah satunya adalah kreditur. Dengan adanya hal tersebut maka disitulah terdapat bentuk perlindungan terhadap kreditur. Karna dengan adanya pengumuman tersebut, maka semua pihak yang berkepentingan terhadap perseroan tersebut mengetahui akan diadanya pengambilahan atau Akuisisi oleh pemegang Saham yang baru. Selanjutnya dalam rangka pemberian perlindungan hukum terhadap kreditur, kreditur diberikan waktu paling lambat 14 (empat belas) hari untuk mengajukan keberatan sebelum RUPS memutuskan rancangan pengambilalihan. Kreditur dianggap menyetujui rancangan pengambilalihan apabila Apabila kreditur tidak mengajukan keberatan dalam jangka waktu tersebut. Dan kemudian apabila kreditur menyampaikan keberatan, maka keberatan tersebut harus disampaikan dalam Rapat Umum Pemegang Saham guna untuk mendapatkan penyelesaian. Berdasarkan Pasal 127 Ayat (7) UUPT, apabila keberatan kreditur tidak dapat diselesaikan, maka pengambilalihan tidak dapat dilaksanakan.

5. Analisis Studi Kasus PT. Bank Pundi Indonesia diakuisisi menjadi atas nama PT. Bank Pembangunan Daerah Banten

Berkaitan dengan adanya proses peralihan PT. Bank Pundi Indonesia menjadi PT. Bank Pembangunan Daerah Banten, menimbulkan ketidakpastian hukum dimana sebelumnya PT. Bank Pundi Indonesia merupakan pemegang jaminan hak tanggungan atas sebidang tanah Hak Milik Nomor 6864/Kelurahan Sumbersari seluas $122 \mathrm{M}^{2}$ (seratus dua puluh dua meter persegi) sesuai dengan Sertifikat Hak Tanggungan Nomor: 820/2013 peringkat pertama serta perubahan Sertifikat Hak Tanggungan Nomor: 1018/2014 peringkat kedua.

Akuisisi yang dilakukan oleh PT. Bank Pundi Indonesia khususnya dalam perjanjian kredit tersebut, Pihak Pertama selaku pemberi hak tanggungan memberikan ketidakjelasan atas status dan/atau hubungan hukum kepada Pihak Pertama, apakah Pihak Pertama selaku debitur masih memiliki hubungan hukum dengan PT. Bank Pembangunan Daerah Banten dan bagaimana status jaminan atas sebidang tanah Hak Milik tersebut serta terdapat perjanjian (Condional Sale-Purchase Agreement) yang mensyaratkan kondisi-kondisi tertentu yang harus terjadi pasca pengambilalihan izin dan nama PT. Bank Pundi Indonesia menjadi PT. Bank Pembangunan Daerah Banten guna dapat mengidentifikasikan perlindungan hukum, kedudukan para pihak dan kepentingan pihak ketiga dalam proses akuisisi tersebut khususnya terkait hak tanggungan atas sebidang tanah Hak Milik tersebut yang menjadi objek perjanjian kredit.

\section{PENUTUP}

Pada dasarnya karakteristik akuisisi perusahaan, hanya mengubah status pemilik saham yaitu beralih dari pemegang saham perseroan terakuisisi kepada pemegang saham pengakuisisi. Selain memperhatikan prinsip-prinsip minimal quorum dan minimal volting, perusahaan juga harus memperhatikan beberapa

David Prasetyo, Peralihan Pemegang Hak Tanggungan Atas Akuisisi Perseroan Terbatas. 
kepentingan dalam melakukan usaha karena akuisisi merupakan suatu perbuatan hukum perusahaan yang mempunyai implikasi penting bagi pihak terkait. Kedudukan kreditur dan debitur dalam proses akuisisi perusahaan adalah sama karena terhadap pengambilalihan suatu perusahaan khususnya dalam akuisisi harus terdapat perjanjian yang mensyaratkan kondisi-kondisi tertentu yang harus terjadi pasca pengambilalihan guna dapat mengidentifikasikan perlindungan hukum, kedudukan para pihak dan kepentingan pihak ketiga serta akibat hukumnya dalam proses akuisisi tersebut. Perlunya dilakukan perubahan Undang-Undang Perseroan Terbatas terkait perlindungan hukum terhadap mitra usaha lainnya dari perseroan, karena menimbulkan ketidakpastian hukum apabila dalam pengambilalihan suatu perusahaan terdapat perikatan dengan pihak lain sebelumnya. Perlunya dicantumkan dalam bab tersendiri dalam Undang-Undang Perseroan Terbatas terkait perjanjian yang mensyaratkan kondisi-kondisi tertentu yang harus terjadi pasca pengambilalihan suatu perusahaan.

\section{DAFTAR PUSTAKA}

Albertus, Andreas, 2010. Hukum Fidusia, Malang: Penerbit Selaras.

Aliminsyah dan Padji, 2003. Kamus Istilah Keuangan dan Perbankan, Jakarta: Penebar Swadaya.

Arifin, Johar, dan Muhammad Fakhrudin, 2001. Kamus Pasar Modal, Akuntansi, Keuangan dan Perbankan.

Atmaja, Setia. Lukas, 2003. Manajemen Keuangan, Yogyakarta: Edisi Revisi, Yogyakarta.

Firdaus, Rahmad dan Maya Arianti, 2004. Manajemen Perkreditan Bank, Bandung: Alfabeta.

Fuady, Munir, 2008. Hukum Perusahaan Dalam Paradigma Hukum Bisnis, Bandung: Citra Aditya Bakti.

---------, 2014. Hukum Tentang Akuisisi, Take Over, dan LBO, Citra Aditya, Bandung.

Husnan, Suad dan Enny Pujiasturi, 2012. Dasar-Dasar Manajemen Keuangan, Edisi 6. Yogyakarta: UPP-AMP YKPN.

Kansil, C. S. T, 2001. Kamus Istilah Aneka Hukum, Jakarta: Pustaka Sinar Harapan.

Kitab Undang-Undang Hukum Perdata (Burgerlijk Wetboek voor Indonesie).

Lesmana, Fuji Jaya, 2012,Perbedaan Kinerja Keuangan dan Abnormal Return Sebelum dan Sesudah Akuisisi di BEI, Trikonomika, Volume 11, No.2, Desember 2012, ISSN 1411-514X, 2012.

David Prasetyo, Peralihan Pemegang Hak Tanggungan Atas Akuisisi Perseroan Terbatas. 
Lipton dan Abraham Herzberg, Philip, 1995. Undertanding of Company Law, Australia : Corporate Education Services.

Marzuki, Usman et.al., 1994. ABC Pasar Modal Indonesia, Jakarta: Institut Bankir Indonesia.

Moin, Abdul, 2004. Akuisisi, Merger \& Diversi, Yogyakarta: Ekonisia Kampus Fakultas Ekonomi UII.

Muhammad, Abdulkadir, 2002. Hukum Perusahaan Indonesia, Cetakan Keempat Revisi, Bandung: Citra Aditya Bakti.

Pasaribu, Bismark Fernando, 2015. Rowland, Manajemen Strategi Lingkungan Internal Organisasi, Universitas Gunadharma.

Pandu, Yudha, 2008. Himpunan Peraturan Perundang-undangan Jaminan Fidusia dan Hak Tanggungan, Jakarta: Indonesia Legal Center Publishing.

Purwosutjipto, H.M.N., 1988. Pengertian Pokok Hukum Dagang Indonesia 2, Jakarta: Penerbit Djambatan.

Slamet B. Noor, 1988, Kamus Akuntansi, Majalah Keuangan, Jakarta.

Soekardono, 1985. Hukum Dagang Indonesia, Jilid I, Jakarta: Bagian Kedua, Rajawali.

Supramono, Gatot, 2009. Perbankan dan Masalah Kredit, Jakarta: Rineka Cipta.

Sutantya, R.T. dkk, 1991. Hukum Koperasi Indonesia, Jakarta: Raja Grafindo Persada.

Tobink, Riduan dan Bill Nikholaus, 2003. Kamus Istilah Perbankan, Jakarta: Atalya Rileni Sudeco.

Undang-Undang Nomor 5 Tahun 1960 tentang Peraturan Dasar Pokok-Pokok Agraria.

Undang-Undang Nomor 4 Tahun 1996 tentang Hak Tanggungan Atas Tanah Beserta Benda-Benda Yang Berkaitan Dengan Tanah.

Undang-Undang Nomor 40 Tahun 2007 tentang Perseroan Terbatas.

David Prasetyo, Peralihan Pemegang Hak Tanggungan Atas Akuisisi Perseroan Terbatas. 